\title{
Clinical and epidemiological characterization of sporotrichosis in dogs and cats (São Paulo, Brazil)
}

\author{
Caracterização clínica e epidemiológica da esporotricose em cães e \\ gatos (São Paulo, Brasil)
}

\author{
Claudio Nazaretian Rossi ${ }^{1}$; Juliana Odaguirii; Carlos Eduardo Larsson ${ }^{3 *}$
}

\begin{abstract}
The present study retrospectively characterized canine and feline sporotrichosis in male and female individuals of various ages. The patients had been attended at the Dermatology Service of a university veterinary hospital and the diagnosis had been confirmed by isolation and identification of Sporothrix spp in culture media. The study obtained and analyzed medical records from a period of 19 years (19932011). From the evaluated sample, 37 animals were considered for the study, including eight $(21.6 \%)$ dogs and $29(78.4 \%)$ cats. The patients were mostly male (30/37-86.5\%) and had mean ages of 79.5 months for dogs and 36.3 months for cats. Most of the patients had no defined breed (25/37-67.6\%). The localized cutaneous form of the disease was most prevalent (25/37-67.6\%), and all cases presented positive histopathological diagnoses. Among the cats with sporotrichosis, infection was also observed in animals and/or humans that lived with these cats in 17/37 (45.9\%) cases. However, none of the affected dogs appeared to spread the infection, as there were no clinical signs that were consistent with the disease. Sporotrichosis was most prevalent among male mixed-breed cats, most of which had a clinical presentation that was consistent with the localized cutaneous form of the disease. In the studied sample, cats constituted an important source of infection for animals and humans living in the same household.

Key words: Sporotrichosis, mycosis, epidemiology, dogs, cats
\end{abstract}

\section{Resumo}

$\mathrm{O}$ presente estudo caracterizou retrospectivamente a esporotricose canina e feline em machos e fêmeas de distintas idades. Os pacientes foram atendidos no Serviço de Dermatologia de um hospitalveterinário escola e o diagnostico foi confirmado pelo isolamento e identificação de Sporothrix spp em meio de cultura. Foram obtidas e analizadas as fichas clínicas de um período de 19 anos (1993-2011). Da casuística avaliada, 37 animais foram considerados para o estudo, incluindo $8(21,6 \%)$ cães e 29 $(78,4 \%)$ gatos. Os pacientes foram na sua maioria machos $(30 / 37-86,5 \%)$ com média de idade de 79,5 meses entre os caninos e 36,3 meses dentre os felinos, sendo a maioria dos pacientes sem precisa definição racial (25/37-67,6\%). A forma tegumentar localizada da enfermidade foi a mais prevalente (25/37-67,6\%), sendo que na totalidade dos casos o diagnóstico histopatológico apresentou-se positivo. Em relação aos gatos esporotricóticos, observou-se infecção em animais e/ou humanos que com eles coabitavam em 17/37 (45,9\%) dos casos. Já dentre os cães, nenhum pareceu disseminar a infecção, uma vez que não foram observados manifestações clínicas compatíveis com a enfermidade nos seus

\footnotetext{
${ }^{1}$ Prof. Adjunto do Instituto de Ciências da Saúde, Curso de Medicina Veterinária da Universidade Paulista, UNIP, São Paulo, SP, Brasil. E-mail: claudiorossi@usp.br

${ }^{2}$ Discente do Programa de Pós-Graduação em Clínica Veterinária, Dept ${ }^{\circ}$ de Clínica Médica, Faculdade de Medicina Veterinária e Zootecnia da Universidade de São Paulo, FMVZ/USP, São Paulo, SP, Brasil. E-mail: juliana_odaguiri@hotmail.com

${ }^{3}$ Prof. Titular do Dept ${ }^{\circ}$ de Clínica Médica da Faculdade de Medicina Veterinária e Zootecnia, FMVZ/SP, São Paulo, SP, Brasil. E-mail: larsderm@usp.br

* Author for correspondence
} 
contatantes. A esporotricose foi mais prevalente em felinos machos, sem precisa definição racial e, na sua maioria, com apresentação clínica compatível com a forma cutânea localizada da doença. $\mathrm{Na}$ amostra estudada, os gatos constituíram-se em importante forma de infecção de contatantes humanos e animais vivendo na mesma residência.

Palavras-chave: Esporotricose, micose, epidemiologia, cães, gatos

\section{Introduction}

Sporotrichosis is a subacute or chronic skin disease that is caused by dimorphic fungus (CAMPBELL, 1998; GROSS et al., 2009) included in the Sporothrix species complex (OLIVEIRA et al., 2011). Infections have been described in humans, dogs, cats, horses, camels, rats, mice, dolphins, primates and xenarthrans (IRIZARRYROVIRA et al., 2000).

Sporotrichosis occurs in Africa, Australia, India, Japan and the Americas, but is rare in Europe. High occurrence has been observed in Latin America, especially in Brazil (BARROS; PAES; SCHUBACH, 2011). The disease is the most commonly diagnosed subcutaneous mycoses in Latin America (LACAZ et al., 2002). The geographic distribution and epidemiology of the disease suggest that the climate, temperature and relative humidity of the air influence the perpetuation of the fungus under saprobiotic conditions (CAMPBELL, 1998). The disease has been frequently diagnosed in the southeast of Brazil, especially in the state of Rio de Janeiro (SCHUBACH et al., 2004a; SCHUBACH et al., 2005, 2006; BARROS et al., 2010; PEREIRA et al., 2010). The disease is also found in São Paulo (OTSUKA; LARSSON, 2004; ROSSI; ODAGUIRI; LARSSON, 2013) and, to a lesser extent, Minas Gerais (NOGUEIRA et al., 1995) and the state of Rio Grande do Sul in the southern regions of the country (NOBRE et al., 2002; MADRID et al., 2008).

Sporotrichosis usually results from the traumatic inoculation of Sporothrix spp in the dermis. The fungus is spread through contact with contaminated soil, penetration of thorns or wood chips, scratching, direct contact with or biting from infected animals or inhalation (LARSSON et al., 1989; LEME et al., 2007). In dogs, sporotrichosis is most common among hunting animals. No sex or age predisposition has been reported in these species (GROSS et al., 2009). As for cats, males are more predisposed to sporotrichosis because of their habit of wandering away from home (GROSS et al., 2009). The disease is believed to be acquired through pathogen inoculation by infected nails or teeth from other cats (WERNER; WERNER, 1994).

Both cutaneous and extracutaneous manifestations of sporotrichosis can occur in humans and animals. In humans, the cutaneous form of the disease can be classified as localized, disseminated or cutaneous lymphatic (SAMPAIO; RIVITTI, 2007). The animal classification is based on human classification and it has limitations, especially when applied to cats (a high frequency of fungemia associated with the presence of multiple cutaneous lesions are observed in feline cases). In many cases the feline sporotrichosis resembles the disseminated form observed in human patients (SCHUBACH et al., 2004b). Skin lesions tend to be grouped and localized at the site of inoculation ("sporotrichotic chancre") of the agent (GROSS et al., 2009; LARSSON, 2011; SCHUBACH; MENEZES; WANKE, 2012), which is the most common manifestation that is observed in dogs (WERNER; WERNER, 1994). In cats, the regional lymph nodes can be affected (the cutaneous lymphatic form of the disease), and the self-inoculation of the organisms can also elicit new lesions. New lesions occur when cats lick their infected wounds and later lick areas that are free of the infection (SCHUBACH et al., 2004a; GROSS et al., 2009; LARSSON, 2011). The systemic form of the disease is rare in humans and dogs (BARROS et al., 2001), however in cats 
it occurs more frequently and can result from the aerial transmission of spores (CAMPBELL, 1998). This form of the disease is most commonly observed concomitantly with immunosuppression that is caused by corticosteroids (GROSS et al., 2009), but cats may present a systemic form of the disease even in the absence of apparent immunosupression (SCHUBACH et al., 2004a).

Diagnosis can be made through fungal cytology (Quick Panoptic method, Gram, Wright and Giemsa fluorescent antibodies), histopathology (Gomori methenamine silver as an special stain) or immunohistochemistry (MIRANDA et al., 2011; PEREIRA et al., 2011) of skin lesions. Fungal culture and subsequent identification is an elective method for the definitive diagnosis of sporotrichosis (WERNER; WERNER, 1994; SCOTT; MILLER JUNIOR; GRIFFIN, 2001; SCHUBACH et al., 2006).

A variety of antifungal drugs has been used in the treatment of human and animal sporotrichosis (NOBRE et al., 2002, LARSSON, 2011) and the typical orally administered treatment protocol often includes halogenated drugs $(20 \%$ potassium or sodium iodide) or imidazole and triazole derivatives (LARSSON, 2006; PEREIRA et al., 2010; LARSSON, 2011; SCHUBACH; MENEZES; WANKE, 2012).

The present study provided a clinical and epidemiological characterization of canine and feline sporotrichosis that had been diagnosed at a university veterinary hospital in the municipality of São Paulo.

\section{Materials and Methods}

A retrospective study was conducted on the clinical cases of canine and feline sporotrichosis between January 1993 and December 2011. The cases were selected among animals that had been attended at the Dermatology Service of the Department of Internal Medicine (DIM) and the
Veterinary Hospital (HOVET) in the School of Veterinary Medicine and Animal Science at the University of São Paulo (FMVZ-USP).

Inclusion criteria were all ages and both genders of canine and feline patients with a diagnosis of sporotrichosis that had been initially characterized by at least a fungal culture, histopathology or fungal cytology. Those that had a presumptive diagnosis by histopathology or fungal cytology had been confirmed as positive by isolation and identification of Sporothrix spp in culture media. Were used the following methods to the diagnosis of sporotrichosis: 1. a positive fungal culture in Sabouraud dextrose agar that was prepared in Petri dishes with chloramphenicol $(0.1 \mathrm{~g} / 1,000 \mathrm{~mL})$ and actidione $(0.8 \mathrm{~g} / 1,000 \mathrm{~mL})$ at the Institute of Biomedical Sciences (Instituto de Ciências Biomédicas ICB) of USP. The Petri dishes were incubated at $25^{\circ} \mathrm{C}$ for 30 days, the first reading was recorded after 15 days of incubation and the next reading was recorded after 30 days. The identification of the fungi was based, at first, on the macro- and microscopic characteristics of the colonies and later, potential colonies were subcultured in brainheart infusion agar $(\mathrm{BHI})$ at $37^{\circ} \mathrm{C}$ for conversion into the yeast stage of Sporothrix spp (LACAZ et al., 2002); 2. a histopathological examination of a fragment, stained with periodic acid-Schiff (PAS) and hematoxylin-eosin (HE), that had been obtained from an incisional biopsy of the lesion at the São Paulo Laboratory of Dermatopathology (Laboratório Paulista de Dermatopatologia); 3. and a gram-stained fungal cytology at the Laboratory of Clinical Pathology at the HOVET, FMVZ-USP.

Animals that had been considered positive for the disease were classified according to the clinical presentation of the disease as localized or disseminated cutaneous disease and cutaneous lymphatic disease. The data were displayed in a spreadsheet and grouped according to species, age and breed. 


\section{Results}

Among a total of 37 cases of sporotrichosis that had been identified within the period of 19 years, eight (21.6\%) were dogs, and 29 (78.4\%) were cats, with a proportion of 3.6 cats being observed for each canine patient with the disease. The 29 cats included eight animals $(27.6 \%)$ that had a defined breed (DB) - including seven Siamese and one Persian - and 21 animals (72.4\%) with no defined breed (NDB); concerning the dogs, four (50\%) had DB (two Boxers, one Saint Bernard and one Brazilian Terrier) and four (50\%) were NDB. The mean age of the cats with sporotrichosis was 36.3 months, and the ages ranged from three to 108 months. For dogs, the mean age was 79.5 months, and the ages ranged from 36 to 120 months. Most of the cats (23-79.3\%) and dogs (seven-87.5\%) were male. The majority of the animals with sporotrichosis $(67.6 \%, 21$ cats and four dogs) presented the localized cutaneous form of the disease, while $27.0 \%$ of the animals (six cats and four dogs) presented the disseminated cutaneous form, and 5.4\% (two cats) had the systemic form of the disease. A total of $72.4 \%$ of the cats had the localized form of the disease, and $20.7 \%$ of the cats had the disseminated cutaneous form. For the dogs, these clinical presentations were distributed evenly (50\% each).

For $17 / 37$ (45.9\%) of the cats that were positive for sporotrichosis, fungal infection was verified in animals and/or humans that lived in the same household, whereas none of the humans or animals that had been in contact with the dogs that were positive for sporotrichosis showed clinical signs of infection. Presumptive diagnosis was established through fungal cytology $(8 / 13$ or $61.5 \%$ of the analyzed samples), fungal culture (13/17 or $76.5 \%)$ and histopathology of the biopsied lesions (37/37 or $100 \%$ ). A positive diagnosis was achieved by histopathology in four $(10.8 \%)$ of the animals for which diagnosis was not initially obtained through culture. All cases had been confirmed as positive by isolation and identification of Sporothrix spp in culture media.

\section{Discussion}

In the present study, a higher incidence of sporotrichosis was observed in cats compared to dogs. This pattern may have occurred because of the greater permissiveness of cat owners, whose pets are considered to be outdoor animals, in allowing access to the extra-domiciliary environment. Access to the external environment could facilitate cats' contact with potential sources of infection. In São Paulo, Otsuka and Larsson (2004) and Rossi, Odaguiri and Larsson (2013) also reported a greater proportion of cats in relation to the number of affected dogs (respectively 10:1 and 5.7:1). This pattern has also been reported in the United States (California) by Crothers et al. (2009); these authors observed a catdog ratio of $3.5: 1$. The elevated susceptibility of cats to intermediate mycosis becomes more evident when considering that the demand for nosocomial care at the FMVZ-USP between 2006 and 2010 was approximately one feline for every 13 canine patients.

Regarding the breed of the studied cats, 21 (72.4\%) had no defined breed (NDB), which is consistent with the values described by other authors (OTSUKA; LARSSON, 2004; PEREIRA et al., 2010; ROSSI; ODAGUIRI; LARSSON, 2013) which reported, respectively, that $84 \%, 83.2 \%$ and $82.4 \%$ of cats with sporotrichosis had no defined breed, which is approximately 15\% higher than Crothers et al. (2009) finding of 57.1\%. The higher occurrence of the disease in Siamese cats may have been the result of a disproportionately high number of Siamese cats being observed at the referred service. Among the dogs, four (50.0\%) were NDB, which is consistent with the values that were reported by Schubach et al. (2006) and Crothers et al. (2009) (50\% and $52.3 \%$, respectively) and slightly higher of those of $33 \%$ observed by Rossi, Odaguiri and Larsson (2013). No racial predisposition was noted among the affected dogs. The difference in the breed frequency that was observed for both dogs and cats may have been caused by a greater supply of mixedbreed animal owners at the HOVET. 
With respect to age, there appeared to be a higher frequency of affected adult animals for cats and dogs. However, it should be noted that the age distribution of animals that are treated at the HOVET has not been determined, which prevents a more detailed analysis of the percentiles that are reported in the present study. Regarding the age predisposition for sporotrichosis, the literature suggests that the disease has been diagnosed in cats between four and six years old (MADRID et al., 2008; ROSSI; ODAGUIRI; LARSSON, 2013). Furthermore, Crothers et al. (2009) and Pereira et al. (2010) found mean ages of 64.8 and 24 months, respectively, for cats that were affected by this disease. In the present study, the mean age of affected dogs (79.5 months) exceeds the ages that were reported by Schubach et al. (2006) and Crothers et al. (2009), which were both approximately 48 months.

Concerning gender, the majority of the cats and dogs were males. According to the literature, similar observations have been described by other authors (LARSSON et al., 1989; OTSUKA; LARSSON, 2004; SCHUBACH et al., 2004a; LARSSON, 2006; MADRID et al., 2008; CROTHERS; WHITE; AFFOLTERT, 2009; PEREIRA et al., 2010; ROSSI; ODAGUIRI; LARSSON, 2013). This trend may be caused by males being allowed greater extradomiciliary access than females, which would result in more involvement in fights (for females or territory) and more predation. Schubach et al. (2006) also reported similar percentiles for affected male (52.3\%) and female (47.7\%) dogs among 44 studied animals.

The present results also indicate that most cats with sporotrichosis $(72.4 \%)$ had the localized cutaneous form of the disease. On the contrary, dogs had equal amounts of the localized and disseminated cutaneous forms of the disease. These values are similar from those observed by Rossi, Odaguiri and Larsson (2013) but differ from the values that were reported by Madrid et al. (2008) and Crothers, White and Affoltert (2009); among cats, these authors reported a higher prevalence of the disseminated cutaneous form of the disease. This difference may be caused by the shorter time interval between infection and initial care, or it could be related to the immune status of the evaluated animals. However, the results observed for affected dogs in the present study are consistent with the results that were reported by Crothers et al. (2009); they also noted a prevalence of $50 \%$ for both the localized and disseminated cutaneous forms of the disease. These researchers also found that systemic sporotrichosis, which was not observed in the present study, is extremely rare in dogs (WERNER; WERNER, 1994).

Regarding the humans and other animals in the same household that were infected by cats with sporotrichosis, the present results are consistent with the results that were reported by Barros et al. (2001). These researchers conducted a 14-year (1987-2000) casuistic study of human cases of sporotrichosis that were diagnosed at the Evandro Chagas Institute in Rio de Janeiro, Brazil, and they found that 54 out of 79 patients (68.4\%) reported having been scratched by or having had contact with infected cats. Madrid et al. (2008) found the same zoonotic potential in $20 \%$ of feline cases. Furthermore, Schubach et al. (2006), reported being able to diagnose different clinical presentations of sporotrichosis in 759 human patients from Rio de Janeiro within a period of seven years (1998-2004). Among those human patients, $83.4 \%$ reported having had previous contact with cats, and $55.8 \%$ reported having received injuries from cats. According to the authors, the zoonotic potential of cats is demonstrated by the isolation of Sporothrix spp from fragments of skin lesions and material from the nails and oronasal cavities of the animals. Actually the cat has taken an important role in the epidemiological chain of sporotrichosis transmission, and human infection by cats has been highlighted in Brazil (SCHUBACH et al., 2005). Furthermore, according to Gross et al. (2009), the disease in cats represents a substantial risk to public health. Domestic cats free access to the external environment and their innate habits, such 
as the burying of feces, fighting with other animals and climbing and sharpening their claws on trees, may predispose them to becoming carriers. They later serve as sources of infection to humans and other animals through bites and scratches, fights and contamination through breaks in the skin (LARSSON et al., 1989).

Concerning the humans and other animals that were in contact with the infected dogs, there were no signs of infection. This finding coincides with the results from Schubach et al. (2006) and Barros et al. (2010). According to those authors, dogs have no significant role in the epidemiological chain of transmission for sporotrichosis, and disease transmission from dogs to humans has not been demonstrated. According to Dunstan et al. (1986), animal-human transmission is restricted to feline sporotrichosis, presumably because of the variety of forms that are found in feline tissue and exudates.

In the present study, it should be noted that presumptive diagnosis of the causal agent was established by histopathology in $100 \%$ of the cases. Larsson (2006) and Crothers et al. (2009) were able to make a histopathological diagnosis in $91.7 \%$ to $95.5 \%$ of the material that was collected through soft tissue biopsies in cats. This result is also largely in keeping with Schubach et al. (2004a) finding of the yeast form in $62.2 \%$ of the histopathological examinations that were performed on biopsy material from skin lesions. The results of the agent isolation, which is evidenced by the fungal culture (76.5\%), are lower than those detected by Crothers et al. (2009), who obtained $94.1 \%$ positive cultures. Furthermore, the fact that the agent could not be isolated in $10.8 \%$ of the samples that were initially subjected to the fungal culture (even though it could be detected by histopathology) has been reported by these authors, which indicates a need for more than one test to diagnose this zoonosis properly. Finally, diagnosis was initially obtained from fungal cytology in $61.5 \%$ of the cats, which corroborates the results of Pereira et al. (2010), who noted a sensitivity of approximately $78.9 \%$ for fungal cytology. According to Gross et al. (2009), the large number of organisms that can be found in fungal cytology and histopathology is characteristic of this species, which allows the confirmation of the diagnosis.

\section{Conclusions}

Sporotrichosis has been found to be more prevalent in male cats with no defined breed. The patients mostly present clinical signs that are consistent with the localized cutaneous form of the disease. In terms of zoonotic transmission, cats seem play an important role in the epidemiology of sporotrichosis.

\section{References}

BARROS, M. B. L.; SCHUBACH, A. O.; GALHARDO, M. C. G.; SHUBACH, T.; MONTEIRO, C.; REIS, R. S.; ZANCOPÉ-OLIVEIRA, R. M.; LAZÉRA, M. S.; CUZZI-MAYA, T.; BLANCO, T. C.; MARZOCHI, K. B.; WANKE, B.; VALLE, A.C. Sporotrichosis: an emergent zoonosis in Rio de Janeiro. Memórias do Instituto Oswaldo Cruz, Rio de Janeiro, v. 96, n. 6, p. 777-779, 2001.

BARROS, M. B. L.; SCHUBACH, T. P.; COLL, J. O.; GREMIÃO, I. D.; WANKE, B.; SCHUBACH, A. Esporotricose: a evolução e os desafios de uma epidemia. Revista Panamericana de Salud Publica, Washington DC, v. 27, n. 6, p. 455-460, 2010.

BARROS, M. B.; PAES, R. A.; SCHUBACH, A. O. Sporothrix schenkii and Ssporotrichosis. Clinical Microbiology Reviews, Washington DC, v. 24, n. 4, p. 633-654, 2011.

CAMPBELL, I. Esporotricose. In: ZAITZ, D.; CAMPBELL, I.; MARQUES, A. S.; RUIZ, L. R.; SOUZA, V. M. (Ed.). Compêndio de micologia médica. Rio de Janeiro: Editora Médica Científica, 1998. p. 123137.

CROTHERS, S. L.; WHITE, S. D.; IHRKE, O. J.; AFFOLTERT, V. K. Sporotrichosis: a retrospective evaluation of 23 cases seen in northen California (19872007). Veterinary Dermatology, Oxford, v. 20, n. 4, p. 249-259, 2009.

DUNSTAN, R. W.; LANGHAM, R. F.; REIMANN, K. A.; WAKENELL, P. S. Feline sporotrichosis: a report of 
five cases with transmission to humans. Journal of the American Academy of Dermatology, St. Louis, v. 15, p. 37-45, 1986.

GROSS, T. L.; IHRKE, P. J.; WALDER, E. J.; AFFOLTER, V. K. In: (Ed.). Doenças de pele do cão e do gato - diagnóstico clinico e histopatológico. 2. ed. São Paulo: Roca, 2009. p. 298-301.

IRIZARRY-ROVIRA， A. R.; KAUFMAN， L.; CHRISTIAN, J. Á.; REBERG, S. R.; ADAMS, S. B.; NICOLA, D. B. de; RIVERS, W.; HAWKINS, J. F. Diagnosis of sporotrichosis in a donkey using direct fluorescein-labeled antibody testing. Journal of Veterinary Diagnostic Investigation, Columbia, v. 12, p. 180-183, 2000.

LACAZ, C. S.; PORTO, E.; MARTINS, J. E. C.; HEINS-VACARRI, E. M.; MELO, N. T. Esporotricose e outras micoses gomosas. In: (Ed.). Tratado de micologia médica. 9. ed. São Paulo: Savier, 2002. p. 479497.

LARSSON, C. E. Esporotricose. Brazilian Journal of Veterinary Research and Animal Science, São Paulo, v. 48, n. 3, p. 250-259, 2011.

Micoses profundas. In: CONGRESSO PANAMERICANO DE CIÊNCIAS VETERINÁRIAS, 20.; CONGRESSO CHILENO DE MEDICINA VETERINÁRIA, 14., 2006, Santiago. Proceedings... Santiago, Chile: MEVEPA, 2006. p. 1-10.

LARSSON, C. E.; GONÇALVES, M. A.; ARAÚJO, V. C.; DAGLI, M. L. Z.; CORREA, B.; FAVA-NETO, C. Esporotricose felina: aspectos clínicos e zoonóticos. Revista do Instituto de Medicina Tropical de São Paulo, São Paulo, v. 31, n. 5, p. 351-358, 1989.

LEME, L. R. P.; SCHUBACH, T. M. P.; SANTOS, I. B.; FIGUEIREDO, F. B.; PEREIRA, S. A.; REIS, R. S.; MELLO, M. F.; FERREIRA, A. M.; QUINTELLA, L. P.; SCHUBACH, A. O. Mycological evaluation of bronchoalveolar lavage in cats with respiratory signs from Rio de Janeiro, Brazil. Mycoses, Berlin, v. 50, p. 210-214, 2007.

MADRID, M. I.; MATTEI, A.; MARTINS, A.; NOBRE, M.; MEIRELES, M. Feline sporotrichosis in the southern region of Rio Grande do Sul, Brazil: clinical, zoonotic and therapeutic aspects. Zoonoses Public Health, Berlin, v. 57, n. 2, p. 151-154, 2008.

MIRANDA, L.H.; QUINTELLA, L.P.; MENEZES, R.C.; DOS SANTOS, I. B.; OLIVEIRA, R. V.; FIGUEIREDO, F. B.; LOPES-BEZERRA, L. M.; SCHUBACH, T. M. Evaluation of immunohistochemistry for the diagnosis of sporotrichosis in dogs. The Veterinary Journal, London, v. 190, n. 3, p. 408-411, 2011.
NOBRE, M. O.; MEIRELES, M. C.; CAETANO, D. T.; FAE, F.; CORDERO, M.; MEIRELES, R. M.; APPELT, C.; FERREIRO, L. Esporotricose zoonótica na região sul do Rio Grande do Sul (Brasil) e revisão da literatura brasileira. Revista Brasileira de Ciências Veterinárias, Niterói, v. 9, n. 1, p. 36-41, 2002.

NOGUEIRA, R. H. G.; GUEDES, R. M. C.; CASSALI, G. D.; GHELLER, V. A.; MOREIRA, Y. K. Relato de esporotricose felina ( $S$. schenckii) com transmissão para o homem: aspectos clínicos, microbiológicos e anatomopatológico. Arquivo Brasileiro de Medicina Veterinária e Zootecnia, Belo Horizonte, v. 4, n. 1, p. 43$51,1995$.

OLIVEIRA, M. M.; ALMEIDA-PAES, R.; MUNIZ, M. M.; GUTIERREZ-GALHARDO, M. C.; ZANCOPEOLIVEIRA, R. M. Phenotypic and molecular identification of Sporothrix isolates from an epidemic area of sporotricosis in Brazil. Mycopathologia, Dordrecht, v. 172, n. 4, p. 257-267, 2011.

OTSUKA, M.; LARSSON, C. E. Sporotrichosis in São Paulo (Brazil): clinical and epidemiological features. Veterinary Dermatology, Oxford, v. 15, n. 1, p. 46, 2004.

PEREIRA, A. S.; PASSOS, S. R. L.; SILVA, J. N.; GREMIÃO, I. D. F.; FIGUEIREDO, F. B.; TEIXEIRA, J. L.; MONTEIRO, P. C.; SCHUBACH, T. M. Response to azolic antifungal agents for treating feline sporotrichosis. Veterinary Record, London, v. 166, n. 10, p. 290-294, 2010.

PEREIRA, S. A.; MENEZES, R. C.; GREMIÃO, I. D.; SILVA, J. N.; HONSE, C. O.; FIGUEIREDO, F. B.; SILVA, D. T.; KITADA, A. A.; REIS, E. G.; SCHUBACH, T. M. Sensitivity of citopathological examination in the diagnosis of feline sporotrichosis. Journal of Feline Medicine and Surgery, Philadelphia, v. 13, n. 4, p. 220223, 2011.

ROSSI, C. N.; ODAGUIRI, J.; LARSSON, C. E. Retrospective assessment of the treatment of sporotrichosis in cats and dogs using itraconazole. Acta Scientiae Veterinariae, Porto Alegre, v. 41, n. 1112, p. 1-5, jan. 2013. Disponível em: http://www.ufrgs.br/ actavet/41/PUB\%201112.pdf>. Acesso em: 01 fev. 2013.

SAMPAIO, S. A. P.; RIVITTI, E. A. Micoses profundas: esporotricose. In: (Ed.). Dermatologia. 3. ed. São Paulo: Editora Artes Médicas Ltda, 2007. p. 738742 .

SCHUBACH, A.; SCHUBACH, T.; BARROS, M. B. L.; MONICA, B. L. Epidemic cat-transmitted sporotrichosis. The New England Journal of Medicine, Massachusetts, v. 353, n. 11, p. 1185-1186, 2005.

SCHUBACH, T. M. P.; MENEZES, R. C.; WANKE, 
B. Sporotrichosis. In: GREENE, C. E. (Ed.). Infectious diseases of the dog and cat. 4. ed. Philadelphia: W.B. Saunders Company, 2012. p. 645-650.

SCHUBACH, T. M. P.; SCHUBACH, A.; OKAMOTO, T.; BARROS, B. L.; FIGUEIREDO, F. B.; CUZZI, T.; PEREIRA, S. A.; SANTOS, I. B.; PAES, R. A.; LEME, L. R. P.; WANKE, B. Canine sporotrichosis in Rio de Janeiro, Brazil: clinical presentation, laboratory diagnosis and therapeutic response in 44 cases (19982003). Medical Mycology, Oxford, v. 44, p. 87-92, 2006.

SCHUBACH, T. M. P.; SCHUBACH, A.; OKAMOTO, T.; BARROS, M. B. L.; FIGUEIREDO, F. B.; CUZZI, T.; FIALHO-MONTEIRO, P. C.; PEREZ, M. A.; WANKE, B. Evaluation of an epidemic of sporotrichosis in cats: 347 cases (1998-2001). Journal of the American Veterinary Medical Association, New York, v. 224, n. 10, p. 1623-1629, 2004a.
SCHUBACH, T. M. P.; SCHUBACH, A.; OKAMOTO, T.; FIGUEIREDO, F. B.; PEREIRA, S. A.; LEME, L. R. P.; SANTOS, I. B.; REIS, R. S.; PAES, R. A.; PEREZ, M. A.; MARZOCHI, M. C. A.; FRANCESCONIDO-VALLE, A. C.; WANKE, B. Utilidade do coágulo sanguíneo para o isolamento de Sporothrix schenkii de gatos naturalmente infectados. Brazilian Journal of Veterinary Research and Animal Science, São Paulo, v. 41, n. 6, p. 404-408, 2004b.

SCOTT, D. W.; MILLER JUNUOR, W. H.; GRIFFIN, C. E. Fungal skin diseases: sporotrichosis. In: (Ed.). Muller \& Kirk's small animal dermatology. Philadelphia: W. B. Saunders, 2001. p. 386-390.

WERNER, A.; WERNER, B. Sporotrichosis in man and animal. International Journal of Dermatology, Philadelphia, v. 33, n. 10, p. 692-700, 1994. 